\title{
Democratic Backsliding and the Instrumentalization of Women's Rights in Turkey
} Yeşim Arat (iD

\section{Bogazici University}

This article examines the instrumentalization of women's rights and the transformation of the gender rights regime in the context of democratic backsliding in Turkey. I show how the Islamically rooted Justice and Development Party governments and their allies used women's rights in constructing authoritarian rule and promoting a conservative gender agenda. The governing elites had different needs at different political stages and instrumentalized women's rights to meet those needs. First, they needed to legitimize their rule in a secular context, so they expanded liberal laws on women's rights. Second, in the process of backsliding, they sought to construct and legitimize their conservative ideology, so they reinterpreted existing laws to promote conservative goals. Finally, they wanted to mobilize conservative women in support of the newly authoritarian regime, so they built new institutions and marginalized existing women's NGOs. The article contributes to the literature on regime types and gender rights by shifting the focus from regime type to regime change.

Keywords: Gender rights, regime change, democratic backsliding, women's rights, women in Turkey, instrumentalization of women's rights, democracy, authoritarianism, Turkey, institutional change

\section{T iberal democracies around the world are going through a crisis. ${ }^{1}$ By the end of 2018, the countries where political rights and civil liberties had}

This article began as a paper delivered at the Buffet Institute for Global Studies conference "Law and Politics in Turkey," supported by the Keyman Modern Turkish Studies Program at Northwestern University. I am grateful to the Keyman Program for its support and the organizers for their invitation. I would like to thank Susan Franceschet and the four reviewers of Politics \& Gender for their astute criticisms and constructive comments on the manuscript. I had the good fortune to discuss my article with Zeynep Pamuk, who helped me clear my mind with her piercing remarks. I thank her warmly and very much.

1. In this article, I refer to "liberal democracy" and "democracy" interchangeably. I assume that a democratic regime commits itself to protect both the civil and political liberties of individuals as well as the procedural requirements of universal suffrage, free and fair elections, a competitive party

(C) The Author(s), 2021. Published by Cambridge University Press on behalf of the Women, Gender, and Politics Research Section of the American Political Science Association. This is an Open Access article, distributed under the terms of the Creative Commons Attribution licence (http://creativecommons.org/licenses/by/4.0/), which permits unrestricted re-use, distribution, and reproduction in any medium, provided the original work is properly cited. doi:10.1017/S1743923X21000192 
diminished outnumbered those where these rights had increased (Freedom House 2018). In 2021, Freedom House reported that the number of countries designated as democracies had declined for the past 17 consecutive years (Csaky 2021). Contemporary democracies usually break down over time rather than through a sudden overturn, in a process that has come to be termed "democratic backsliding" (Diamond 1996, 2015). Despite the large literature on the topic, theorists of democracy point out that we still do not know enough about how democratic backsliding takes place (Bermeo 2016; Waldner and Lust 2018). ${ }^{2}$ Yet, we know even less about how backsliding regimes manipulate women's rights and the discourse of women's rights in the process of this transformation. What strategies do governments use to promote or obstruct women's rights, and why do they do so? Are the strategies they use the same during the different stages of democratic backsliding, or do they change over time? What are their implications for women's rights and for regime change? This article addresses these questions in the context of democratic backsliding in Turkey.

The Islamically rooted conservative Adalet ve Kalkınma Partisi (AKP; Justice and Development Party) came to power through democratically held elections in 2002 in Turkey and has remained in power since then. The AKP promised to strengthen Turkish democracy and made some democratizing moves in its early years. However, a process of democratic backsliding began around 2010, and the regime moved steadily in an authoritarian and conservative direction in the following years. While it is impossible to pinpoint dates of regime change precisely because of the incremental nature of the backsliding process, scholars working on Turkey had begun defining its political regime as "competitive authoritarian” by 2015 (Esen and Gümüşcü 2016; Özbudun 2015) and, over the next few years, referred to it increasingly as "authoritarian" (Arat and Pamuk 2019; Arslanalp and Erkmen 2020; Bakıner 2017; Bali 2018; Çalıskan 2018). ${ }^{3}$ A referendum in 2017 was a turning point, as the

system, the rule of law, and accountability (O'Donnell and Schmitter 1986, 8-9; Diamond 1996, 20). Separation of powers between different institutions of the state - namely, the executive, legislature, and judiciary - is a necessary, if not sufficient, condition of democracies to ensure commitment to both liberal rights and procedural requirements.

2. For "Democratic backsliding," I adopt Bermeo's $(2016,5)$ broad definition, which is "state-led debilitation or elimination of any of the political institutions that sustain an existing democracy." These include erosion of civil liberties and political rights as well as deinstitutionalization of the judiciary or the legislative branch.

3. Levitsky and Way $(2002,53)$, who introduced the term "competitive authoritarianism," define it as a political system with "an uneven playing field between government and opposition," which leads to incumbents remaining in power. Yet, unlike in authoritarian regimes, there is still democratic 
country switched to a presidential system that centralized power in the hands of the president and facilitated the encroachment on rights. Freedom House ranked Turkey's political regime as "not free" in 2018, pointing out its "deeply flawed constitutional referendum that centralized power in the presidency, a government that replaced elected mayors with government appointees, arbitrarily prosecuted rights activists and other perceived enemies of the state and continued its purge of state employees" (Freedom House 2018).

This article argues that the AKP instrumentalized women's rights using different strategies at each stage of this process of political change to serve its changing needs. I use the term "instrumentalize" to mean "to make use of" or "to appropriate" in order to promote the interests - or perceived interests - of the governing elites, independent of the impact of these "rights" on the interests of women themselves. The governing elites manipulate women's rights and the women's rights discourse because doing so helps them stay in power, either as democratic leaders or as authoritarian ones (Valdini 2019). Women's rights thus become a mere means or a tool of the governing elites' pursuit of power.

I identify three main strategies and stages in this process: First, when it came to power through democratic elections in 2002, the AKP manipulated women's rights by using a liberal discourse and expanding liberal laws on women's rights to legitimize its rule and enhance its reputation. As the process of backsliding began after 2010, the AKP judiciary reinterpreted the existing egalitarian legal framework that protected women's rights in marriage to promote religious marriage, which threatened women's existing rights but served to propagate the AKP's conservative gender ideology. This move helped the increasingly authoritarian regime consolidate its ideological hegemony in power. Finally, as its authoritarian tendencies increased, the AKP helped establish conservative institutions for women to marginalize existing egalitarian ones. I focus on the establishment of a conservative women's organization to transform - in practice, if not through the legal framework - the regime of gender equality prescribed by the

contestation in the electoral arena, and the media and opposition are not systematically repressed (Levitsky and Way 2002, 54). In this paper, I take an authoritarian regime to be one where civil and political liberties are heavily restricted, the media severely repressed, the separation of powers blurred and power centralized in the hands of an authoritarian leader, rather than one where there is no political contestation at all. It is a regime that Freedom House defines as "not free," as Turkey has been defined since 2018. However, my argument does not depend on accepting any particular threshold between competitive authoritarianism and authoritarianism. I am only interested in a process of steadily increasing authoritarianism. 
constitution into one based on the complementarity of genders. Such an organization both propagated the conservative ideology of the governing elites and reinforced their power by helping to mobilize a conservative female constituency behind the party. The instrumental use of women's rights thus helped the government change the norms and practices of gender rights to promote an illiberal conservative gender ideology while also entrenching its increasingly authoritarian rule.

Studies of the relationship between regime type and gender have focused on how different regimes perform with respect to women's rights. Thus, they take a static picture of both regimes and gender rights. The goal of this article, by contrast, is to illustrate a dynamic process: I aim to show how the governing regime's interests in appropriating women's rights changed in tandem with the process of regime change from a weak liberal democracy to a type of authoritarianism and the transformation of the women's rights regime in that process. While I focus on how the governing elites used women's rights to serve their changing goals at different stages of backsliding, I show that there was an affinity between the political regime change and the gender regime change. Democratic backsliding made it possible for the government to transform the gender equality framework initiated by the founding fathers of the Turkish Republic, while the instrumentalization of women's rights served to promote the interests of the emerging authoritarian regime and entrench its conservative gender ideology.

To explore how the process of backsliding both shaped and benefited from the instrumentalization of women's rights, I first discuss the literature on regime types and women's rights and situate the Turkish case. I then briefly contextualize the nature of gender rights in Turkey before the AKP came to power. The article starts from the period of democratization when the AKP first came to power and traces the transformation of the gender framework through the period of democratic backsliding and increasing authoritarianism. The main argument is organized around three stages of the instrumentalization of women's rights by the governing regime in this process. I theorize these changes using the framework of institutional change developed by Kathleen Thelen (2011). My aim is to bring together feminist debates on regime type and gender equality with a political science approach to institutional change. The article is an interpretative study of the Turkish case based on secondary material. It aims to elaborate the hypothesis that at each stage of democratic backsliding, political regimes have different interests in instrumentalizing women's rights. In this context, the article also explores the affinity between regime change and the transformation of the gender framework. 


\section{THEORETICAL DEBATES ON REGIME TYPES, GENDER POLITICS, AND INSTITUTIONAL CHANGE}

The feminist literature on political systems and gender rights asks which regimes promote gender equality, and when and why they do so (Adams 2007; Donno and Kreft 2019; Lorch and Bunk 2016, 2017; Mama 2013; Sika and Khodary 2012; Svedberg 2019; Tripp 2013, 2019; Valdini 2019). Tripp (2013) argues that democratic regimes seem more likely to achieve higher levels of gender equality than other regime types. Democracies provide the political context in which women's movements can empower themselves to lobby for change. Stronger judiciaries can adjudicate in favor of women's equality. Femocrats within state institutions precipitate improvements in women's status, and for some democratic regimes, there is also the need to abide by changing norms regarding gender equality (Tripp 2013). This was the case in Turkey during the post-1980 period until around the first decade of the 2000s. In line with theories arguing that democratization extends gender rights, democratization in Turkey in the 1990s allowed for and, in turn, grew stronger through the development of a women's movement that successfully promoted women's rights (Arat 2008; Tekeli 2010). Democratic rule created a political space in which women could lobby for their rights. Women pressed for changes in the legal codes and the eradication of gender-based violence. Turkey's candidacy for the European Union in 1999 also provided an opportunity space that further allowed women to successfully promote their cause.

Authoritarian regimes, on the other hand, generally remain behind democratic regimes in terms of promoting women's status (Mama 2013; Tripp 2013). However, some of them do improve women's rights. Donno and Kreft (2019) claim that 25\% of autocracies match or perform better on women's rights than developing democracies and argue that the institutional features of dictatorships shape their capacity for the provision of women's rights. Researchers have different explanations as to why some authoritarian regimes provide rights when others do not. Tripp $(2019,24)$ argues that in Morocco, Algeria, and Tunisia, the secular authoritarian political elites strategically use and extend women's rights "to counter extremist Islamist trends and present a modernizing image of their country abroad." According to Tripp, even Islamist parties feel pressure to adopt women's rights reforms, although they change their positions once in power.

Lorch and Bunk (2016), who study Algeria and Mozambique, claim that promoting women's rights can contribute to the resilience of authoritarian 
regimes. The regime can use women's rights to legitimize its rule and maintain power. It can benefit from women's organizations as a means of co-opting women to draw on their political support. Finally, authoritarian rulers can instrumentalize women's rights to draw a wedge between women's groups, particularly playing on secular groups' fears of Islamic empowerment.

Others underline the importance of international legitimacy and reputation (Adams 2007; Svedberg 2019). International organizations that surveil democratic rights can be more lenient on dictatorships that improve women's rights (Svedberg 2019). In a context in which the authoritarian state is dependent on international aid, adopting feminist politics without necessarily implementing them can provide muchneeded international legitimacy (Adams 2007). Bush and Zetterberg (2021) test this hypothesis and conclude that gender quotas really generate a reputational boost. While these scholars study the relationship between gender and specific regime types, Valdini (2019) uses rational choice theory to argue that male elites decide to include women in politics to maintain their own power regardless of regime type, including in democracies and hybrid regimes.

In the Turkish case, the AKP instrumentalized women's issues to entrench its rule both in its democratic years and in the period of democratic backsliding. A substantial literature on the AKP's gender policies examines its conservative turn and restrictive implications for women's rights (Acar and Altunok 2013; Akkan 2018; Aksoy 2018; Ayata and Doğangün 2017; Candaş and Silier 2013; Cindoğlu and Ünal 2017; Coşar and Yeğenoğlu 2011; Dedeoğlu and Elveren 2012; Doyle 2018; Koyuncu and Özman 2019). Yet the questions these authors pose do not specifically address how the instrumentalization of women's rights served the different needs of the governing elites at each stage of democratic backsliding and contributed to a change in the gender regime. Feminist scholars urge us to examine how institutional change occurs in a gender framework and how governing elites manipulate women's interests in this process (Celis et al. 2013, 16).

I draw on Thelen's (2011) work on institutional change to trace this process in the Turkish case. Thelen's research on historical institutional change explores the conditions under which institutional transformation takes place. She focuses on incremental change taking place within the constraints of existing institutions, where actors who pursue their interests under these conditions can ultimately bring about radical shifts. In this article, I use Thelen's work not to study the regime change that took 
place in Turkey, but the change in the gender regime that replaced the gender equality framework with a conservative gender complementarity one. I draw on Thelen's work because it sheds light on the question of how the gender regime changes in a context of regime change over time. Her work helps me explore how changing institutional constraints shape the strategies political actors within existing institutions use. It sheds light on how these actors instrumentalize women's rights to promote their own political interests. This framework allows me to engage the literature on regime types and gender rights with questions of institutional transformation in an interdisciplinary way.

Thelen (2011) argues that three strategies can be used to bring about transformation in existing institutions: (1) purposeful neglect, (2) redirection of old laws to serve new ends, and (3) displacement through the replacement of old institutions.

I identify institutions as rules, norms, and practices that shape gender rights, following the convention on the subject (Celis et al. 2013). In line with Thelen's framework, I trace how the governing elites first passed liberal reform laws on gender rights when they came to power and then duly ignored them. This helped the power holders legitimize their rule and bolster their reputation using the facade of improving women's rights. During the years of democratic backsliding, the pro-AKP judiciary reinterpreted existing laws to extend religious rights, to the detriment of many women. This helped the AKP regime use the legal framework to promote its conservative gender ideology from the top down. As the governing elites consolidated their power and needed neither secular legitimacy nor legal grounds for extending gender norms, they established new women's institutions that could mobilize women for the AKP and propagate conservative gender norms. The AKP regime sought to marginalize, if not replace, older organizations that upheld the egalitarian legal framework. Thus, I show how incremental changes that helped political authority reproduce itself through law and reform paved the way for extending patriarchal norms in an increasingly authoritarian system.

\section{THE CONTEXT: THE AKP'S CLAIM TO POWER}

The AKP came to power in 2002, not as a religious or an Islamist party, but as a "conservative and democrat" one in a secular state (Yavuz 2009, 79-93; see also Özbudun 2006). Its two predecessors had been closed down by the Constitutional Court of Turkey because their activities abrogated the 
constitutional article protecting secularism. The AKP grew out of the moderate wing of a defunct Islamically rooted party and had roots in political Islam.

At the time, the staunchly secular state elites were deeply suspicions of Islamically rooted politicians. The major organs of the state, including the parliament, the president, the judiciary, and the military, prided themselves on their narrowly defined secularism. The constitution stated that the Republic of Turkey was a secular state and that this feature could not be altered, even though it did not define what secularism entailed. Nevertheless, the secularist state elites expected religion to be confined to the private realm and opposed the public visibility of Islam, including, for example, women's headscarves.

This was a period when the economic liberalization policies of the 1980s, coupled with weak governments, had left the country immune to the economic crises of a globalizing world (Öniş and Keyman 2003). The military intervention of 1980 deinstitutionalized the party system by banning all political parties and encouraging the founding of new parties after the transfer of power to civilians. Even though a process of democratization began after civilians took power in 1983, the coalition governments that ruled the country in the 1990s were weak, tainted with corruption, and ineffective. The electoral system, though procedurally democratic, had a majoritarian bias with a $10 \%$ national threshold that aimed to keep small parties, most significantly the Kurdish population, out of political competition.

Despite these problems, this was also a period shortly after the European Union (EU) formally recognized Turkey's status as a candidate for membership in 1999. The EU expected the state to improve its civil liberties record and meet its human rights criteria for membership (Kubicek 2011). The prospect of an alliance with the EU raised hopes for more democratization and change (Yllmaz 2005). Turkey had never had a strong liberal democracy, but it had an institutionalized procedural democracy, which was liberal enough to allow the AKP - a political party that had roots in political Islam but pledged to respect the secular state and extend civil liberties - to contest elections. The AKP promised to pursue the EU accession goal with more conviction than its secular rivals. The liberal EU legislation could also be a safeguard to protect the AKP from closure by the secularists. Thus the AKP came to power, although it would not fulfill its promise to democratize the country; instead, it initiated a process of democratic backsliding and the emergence of competitive authoritarian rule (Esen and Gümüşcü 2016). 


\section{THE WOMEN'S MOVEMENT}

The AKP sought power not merely under secularist surveillance, but also in a country with a legacy of state feminism and a vibrant women's movement (Arat 1997; Arat and Pamuk 2019, 228-61; Tekeli 1986, 2010). Women who called themselves feminists, including leftists, Kemalists, Kurds, and a few Islamists, together with others who did not claim to be feminists, fought for their rights as women in the context of democratization after the 1980 military intervention. The transition of power from a military to a civilian government took place in 1983 while women were organizing in small groups and sharing their experiences of discrimination. In 1986, when civil society organizations were still under strict state surveillance, women initiated the first public campaign to pressure the government to implement the Convention on the Elimination of All Forms of Discrimination Against Women (CEDAW), which had been signed in 1985. The tradition of upholding gender equality was a legacy of the modernizing, if authoritarian, founding fathers. Consequently, women's public demands for more rights were not seen as threatening the state or the government, even when they were not immediately met (Arat 1998, 118-19). Some prioritized the struggle against domestic violence or the amendment of the legal framework, others made demands for their religious rights as women to wear headscarves in universities, while still others sought recognition of their identities not merely as women, but as Kurdish women. Women protested in the streets, devised creative campaigns, published journals, and institutionalized their struggle for their rights through vibrant civil society organizations (Arat and Pamuk 2019, 228-61; Diner and Toktaş 2010).

By the 1990s, in a context of global feminism on the rise, political parties and the state began responding to women's calls. The Directorate of Women's Status and Problems and later a ministry of state responsible for women's issues were established. Women's studies centers in universities began to disseminate women-centered values in the country. Women began to successfully pressure the state to amend patriarchal laws. In 1998, the parliament accepted a law to protect women against domestic violence, which feminists had put on the political agenda.

Turkey's candidacy for membership in the EU boosted women's efforts to promote their cause (Müftüler-Baç 2005). With strategic pressure by femocrats in various government institutions, the coalition government in power amended the Civil Code in 2001, a year before the AKP came to power (Marshall 2009). The introduction of the Civil Code in 1926, 
which replaced Islamic Sharia, was arguably the most crucial reform that the founding fathers of the Turkish Republic initiated. It abolished polygamy, recognized equal rights in divorce, and granted equal inheritance rights to women. Yet, it needed improvement, and feminists had been fighting for a more progressive amendment since the mid1980s. The amended law recognized joint ownership of property in marriage and eliminated various patriarchal stipulations regarding the division of labor within the family. Property acquired during marriage would be shared in cases of divorce, regardless of formal ownership. In a country where the labor force participation of women was low (World Bank 2020) and most women were housewives, the new code thus aimed to compensate the unremunerated labor of women at home doing domestic work. Following the success of the Civil Code amendment, women continued to pursue other rights that needed political attention at the time the AKP came to power, including the amendment of the Penal Code.

\section{THE AKP'S LIBERAL REFORMS ON WOMEN'S ISSUES AND PURPOSEFUL NEGLECT}

The AKP government came to power in a context in which the women's movement prided itself on its achievements and collaborated with the state. Following its promises for further democratization, the government undertook a series of liberal reforms, including those on women's rights, during its first term in power from 2002 to 2007. The preceding coalition government had initiated democratizing reforms in pursuit of accession to the $\mathrm{EU}$, and the AKP followed suit to further the EU goal (Müftüler-Baç 2005; Tocci 2005). The AKP was a party rooted in Turkey's religious right, but its reforms concerning women were liberal and in line with the established gender equality framework that the women's movement pursued.

In 2004, the government amended the Penal Code. The women's movement at the time had been actively lobbying for an amendment that would extend women's rights on issues concerning gender-based violence. The new code defined crimes related to sexual violence as "crimes against individuals," whereas the old code had categorized them as "crimes against public morality." Punishments for sexual crimes and domestic violence increased. Marital rape and harassment in the workplace were both recognized as crimes punishable by law, which had 
not been the case before. The article of the old code that deferred punishment when a rapist married his victim was dropped. Similarly, articles that distinguished between married and single women and between virgins and sexually active women were abolished (Arat 2008, 406-8; Sarihan 2005). The new AKP government also reinforced the gender equality article of the constitution (Article 10) by adding a clause stipulating that the state would be responsible for establishing gender equality.

A year later, in line with the amendment of the Penal Code, the government initiated the amendment of the Law on Municipalities. With this amendment, the state made it mandatory for municipalities with more than 50,000 inhabitants to establish women's shelters to protect the victims of domestic violence (Coşar and Yeğenoğlu 2011). In 2006, the Prime Ministry collaborated with feminist groups and issued a road map to prevent gender-based violence through a more radical and holistic plan. This initiative listed in detail the responsibilities of all institutions that would have to take action to eradicate violence toward women. Recep Tayyip Erdoğan, the prime minister at the time, was keen to send the message that he was concerned with women's problems, such as gender-based violence, that primarily secular feminists advocated at the time.

These liberal reforms were functional in promoting the AKP's interests (Dağı 2006). They helped promote the popularity, legitimacy, and credibility of the Islamically rooted government, which had promised to democratize and to pursue EU accession, which a large majority of the population supported. During this phase, the AKP was still circumscribed by the secular elites, who controlled the military, the bureaucracy, and the judiciary and were wary of the AKP's religious credentials. To secure its hold on power, the AKP government accommodated the secular elites and assuaged their persistent fears. The reforms were instrumental in dispelling suspicions that the party in power threatened the secular nature of the republic. Improving the legal framework to extend women's rights was thus a politically useful move to communicate to the electorate that the new government would operate within the secular republican framework and could be trusted to remain in power.

There were advantages at the international level as well. Gender-based reforms signaled to the international community that this religiously rooted party was progressive on human rights and endorsed universal values. Moreover, even though the credibility of the EU conditionality 
was high in the early 2000s, Turkey nevertheless had to meet the Copenhagen criteria and improve its human rights record (Kubicek 2011). Extending women's rights provided an opportunity that was not politically costly compared, for example, with curbing the intervention of the military in civilian affairs or recognizing Kurdish language rights, which the EU also expected from Turkey. At the time, the military still had the power to threaten the existence of the AKP, and extending Kurdish rights would have generated opposition from large sections of the population, including the AKP's constituency. Women, unlike Kurds, demanded neither autonomy nor language rights that would challenge the power of the ruling elites. ${ }^{4}$ Recognition by the international community, and especially the $\mathrm{EU}$, would improve the AKP's domestic legitimacy and power as well. Finally, gender rights could be easily ignored, as indeed they were (Coşar and Yeğenoğlu 2011). A female constituency that could punish the incumbent elites in elections was not yet there. The issue of gender quotas never came up. There was no effective fight against gender-based violence (Kandiyoti 2016). In 2019, AKP parliamentarians contested and tried to renege on articles of the amended Penal Code on punishments for sexual crimes (Bianet 2019).

However, at the time, the AKP's attempts to contain secular groups skeptical of a religiously rooted party in power were not successful. By the end of its first term, the secular opposition, both in parliament and in the judiciary, prevented the AKP government from exercising its electoral power. Despite its strong majority in parliament, the AKP could not have its candidate for the presidency elected. At the beginning of the AKP's second term, the secular opposition did not let the government lift the ban against Muslim headscarves (Aksoy 2015).

Under these circumstances, the AKP changed its strategy of containing the secularists and instead intended to circumscribe the power it had (Arat and Pamuk 2019, 101-15). To prevent the secularist high courts from obstructing AKP initiatives, the government decided to democratize the meritocratic structure of the Constitutional Court and the High Council of Judges and Prosecutors through the amendment of laws shaping membership recruitment. This change took place as part of a larger liberalization or democratization package that had to be taken to a referendum in the context of adjustment to the EU acquis.

4. Valdini $(2019,11,127)$ makes a similar point about any underrepresented ethnic group. 
In the process, the government further strengthened the protection of gender equality in constitutional Article 10 and made it a part of the 2010 democratization package. The proposed article stipulated that the state's measures to ensure gender equality could not be interpreted as contrary to Article 10 of the constitution. Hence, there would be no legal grounds to contest affirmative action. It was a message to the electorate that the AKP was concerned with secular women's political issues in the 2010 referendum. Still, many feminists voted no because they did not trust Erdoğan on gender rights. Others argued that the amendment was unnecessary, because if the state was responsible for establishing gender equality, it could take the required measures to achieve this goal without abrogating the equality principle (Koç 2010).

Yet, strengthening Article 10 had another function that would bolster the government against the secularist opposition. It helped divert attention from the major aim of the referendum, which was to help the government reshape the Constitutional Court and the High Council of Judges and Prosecutors by changing the electoral rules of membership (Kalaycığlu 2012). Proposed amendments concerning the judiciary would increase the number of judges sitting on the high courts. The new laws would also allow pro-AKP groups, such as lower-level judges and popularly elected majorities in the parliament, to choose the members of the high courts. Until then, secular professionals of the Court of Cassation and the Council of State had the privilege of shaping the membership of the higher courts based on merit. The referendum package would thus allow the AKP to undermine the secularist hold on the top courts and give the party a chance to gain the judiciary as a political ally. The new Article 10, along with other minor liberal constitutional changes, such as recognizing some privacy rights and abolishing the political immunity of the 1980 coup leaders from accounting for their deeds, would serve to divert focus from the politically controversial amendment, which was aimed at transforming the composition of the high courts (Kalaycığlu 2012). It would make the package look liberal and democratic. Indeed, the EU Enlargement Commission warmly approved and supported the referendum for its democratizing goals (Morelli 2010).

The amendments proposed by the government as a single package were accepted with $58 \%$ of the popular vote. After the referendum, while the amended Article 10 was ignored, the new rules transforming the membership of the judiciary were implemented. Thus, the dominance of the secularist judges in the high courts ended, and the AKP was able to consolidate its power without judicial surveillance. 
The 2010 referendum marked a turning point, after which the AKP governments began to control the courts (Bakıner 2017, 34-35). The strengthening of the gender equality clause, among others, helped obfuscate crucial changes that would allow the government to appoint conservative judges who would loyally support the party's agenda. Soon after the referendum, in 2010, Erdoğan publicly stated that he did not believe in equality between men and women (Pelek 2010). The 2010 referendum that had begun as a democratizing move also initiated the process of backsliding.

By 2011, the AKP government had begun curtailing civil liberties and controlling the media (Esen and Gümüşcü 2016). Nevertheless, the government continued to be careful to promote a liberal image of itself, for both its foreign and domestic constituencies. Turkey thus contributed to the drafting of the 2011 Council of Europe Convention on Preventing and Combating Violence Against Women and Domestic Violence, named the Istanbul Convention for short because it was opened for signature in Istanbul. Turkey was the first country to ratify the convention in its parliament. In line with the Istanbul Convention, in 2012, Turkey's parliament passed a new law that improved and bolstered the 1998 law on the prevention of domestic violence. The pursuit of women's protection against violence was a pragmatic means to appeal to both the secular groups and the AKP's pious constituency. Unlike some feminist demands for quotas or freedom for sexual expression, eradicating violence against women was not a divisive goal. On the contrary, it would mask, or at least balance, the government's increasingly conservative policies supporting women's subordinate and dependent role in the family, such as extending maternal leave for women and making their employment less desirable for employers or encouraging women to work part time. Erdoğan also encouraged all women to give birth to three children (Coşar and Yeğenoğlu 2011). At the time, a showdown with Europe did not seem expedient, and sharing universal values concerning women's protection from violence would be helpful both for diplomatic relations and for sustaining local support for the regime.

While these reformist liberal laws helped the increasingly illiberal governments maintain a liberal image to consolidate their power, none of the reform measures, including the Penal Code and the Istanbul Convention, was implemented. By 2019, the amended articles of both the Penal Code and the Istanbul Convention began to be contested by AKP members. In 2021, Erdoğan withdrew Turkey from the Istanbul 
Convention. The AKP governments, according to Thelen's (2011, 56) terms, drifted through purposeful neglect in a context of change until they had the power to criticize those amendments. Neither the prevention of violence against women nor the amendment of the constitution's gender equality clause was a substantive concern of the AKP governments. Gender-based violence soared, while the AKP became more illiberal (Ulukaya 2015). However, at this stage of institutional change, the liberal reforms and the liberal discourse served to consolidate the power of the AKP governments both domestically and internationally.

\section{LIBERAL INTERPRETATIONS FOR ILLIBERAL ENDS}

The process of backsliding began after the AKP's first term in government, and particularly after 2010, although the exact date can be contested (Bakıner 2017). In 2009, the largest media group in the country, which had exposed a large Islamist embezzlement case, was diminished after it was fined half a billion dollars for alleged tax evasion. Journalists began to be fired based on the instructions of the president, and many others were jailed for their reporting. To weaken the military, the government collaborated with the Islamic Gülen movement, which had infiltrated the judiciary. The Gülen prosecutors and judges arranged two rigged mass trials in 2007 and 2010 at which hundreds of military officers, including the commander in chief of the armed forces, were convicted of conspiring to overthrow the government. After the trials that ended in 2013 and 2012, respectively, the military was no longer a threat to democracy, but instead subservient to increasingly authoritarian civilian rule under which the judiciary was compromised and the media obstructed.

The Gezi protests against the government's restriction of rights and freedoms took place in 2013. By the end of the year, the alliance between the Gülenists and the AKP against the secularist military and judiciary turned into a feud over state power. The separation of powers between the government and the judiciary eroded further during this crisis (Özbudun 2015). In 2014, then Prime Minister Erdoğan was elected president of the country with $52 \%$ of the general vote. At the time, Turkey still had a parliamentary system. Yet, the president had already begun using power in outright defiance of the constitutional limits within which he had to operate. In the June 2015 general 
elections, the AKP lost the electoral majority necessary to form a singleparty government. In November 2015, Erdoğan engineered a repeat general election and regained the electoral support needed for the AKP to form a single-party government (Kalaycığlu 2018). In 2015, by the time the AKP won the national elections for a fourth term, there was, in Levitsky and Way's $(2002,53)$ words, "an uneven playing field between the government and the opposition," such that Turkey could be described as a competitive authoritarian system (see also Esen and Gümüşcü 2016; Özbudun 2015).

During this stage, the AKP government and its allies in the courts appealed to liberal norms to serve their conservative agenda and bring about top-down change involving women's rights through the law. In Thelen's $(2011,56)$ words, they "reinterpreted old rules to serve new ends." In May 2015, the Constitutional Court, which by then was composed of mostly pro-AKP judges under Erdoğan's influence, signed a critical verdict that reinterpreted the "old rules" of the secular constitution to promote religious marriage.

In Turkey, the secular state neither registers nor recognizes religious marriages. Until the 2015 Constitutional Court ruling that annulled the relevant article of the Penal Code, religious marriages could be contracted freely only after a civil marriage. If a religious marriage was contracted prior to a civil marriage, the married couple and the person performing the marriage ceremony could be punished with two to six months' imprisonment. This Penal Code article was legislated in line with Article 174 of the constitution on the protection of the revolutionary laws of the founding fathers. The Civil Code was such a law. Article 174 stipulates that the marriage act, prescribed by the Civil Code that replaced Sharia, has to take place before a civil servant, who registers it as a civil marriage. ${ }^{5}$ This particular article was contested before, in 1999, but the Constitutional Court at the time ruled, unanimously, that it was constitutional (Constitutional Court 2015, 9-10).

By the 2000s in Turkey, at most 3\% of the population contracted only religious marriages without a civil marriage, even though more than $80 \%$ contracted both civil and religious marriages (Altmay and Arat 2007, 64). People could practice their religious rites of marriage as long as they also contracted civil marriages. Even though the practice of contracting civil marriages first and religious ones later was widely endorsed, women's

5. See the text of Article 174 at https:/www.constituteproject.org/constitution/Turkey_2017.pdf? lang=en (accessed July 5, 2021). 
civil society associations nevertheless organized campaigns, as late as the 1990s, to make sure that all marriages were first contracted according to the Civil Code. ${ }^{6}$ The Civil Code provided numerous protections to women in marriage, divorce, and inheritance, as discussed earlier, especially after it was amended in 2001, with the successful lobbying of the women's movement and the priorities of the secular coalition government of the time to harmonize Turkey's laws with those of the EU.

Within this secular legal framework, and in the context of increasing restrictions of rights and the rapid erosion of separation of powers between the executive and the judiciary, a criminal court in Erzurum appealed a case to the Constitutional Court involving a couple who had married in a religious ceremony and a local religious leader who carried it out, without a civil marriage. The Constitutional Court issued a majority ruling that the Penal Code article criminalizing religious marriage without civil registration violated the constitution and annulled the relevant provisions of the Penal Code. Twelve of the 16 judges who adjudicated the case voted for the annulment of the disputed article. The requirement of civil marriage prior to religious marriage was thus dismissed in Turkey. The Federation of Turkish Women's Associations immediately announced that "the judgment would increase the number of men marrying multiple women, underage marriages, paid marriages, and infringements of women's rights in relation to marriages" (Uras 2015). Yet the verdict could not be reversed.

In this historic decision, the court reinterpreted three articles of the constitution by appealing to a decontextualized liberal ideology: Article 20 on the individual's right to demand respect for his or her private and family life and the privacy of private or family life, Article 24 on the freedom of religious belief and conscience, and Article 13 on restrictions that could be made on basic rights and freedoms in line with democracy and the spirit of the constitution (Constitutional Court 2015, 4). The court concluded that Article 10 on equal treatment of citizens was not relevant to the case under contestation. According to the majority opinion, the contested article of the Penal Code was contrary to Article 20 because it restricted the individual's right to privacy and respect for their private life without grounds defined under Article 13. Article 13 specifies that restrictions on basic rights and freedoms cannot be contrary

6. In the 1990s, Prime Minister Turgut Özal's wife Semra Özal founded a civil society organization called the Foundation for the Empowerment and Promotion of Turkish Women that primarily encouraged women who married according to religious rites to contract civil marriages; see https:// www.biyografya.com/biyografi/l1209. 
to the requirements of a democratic order, even though the latter requirements are not defined. The court decided that the requirement of a civil marriage prior to religious marriage was contrary to democratic needs. The aim of Article 20 was to keep the state from intervening in private lives (Constitutional Court 2015, 4). According to the court, the state was being unduly intrusive in shaping its citizens' right to marry as they chose. The court's case assumed a non-interventionist liberal state that defined freedom merely in negative terms, as state restraint from intervention in private lives. In this argument, there was no consideration of gender inequalities in both the private and public realms that obstructed equal democratic participation. The problem of power disparities between men and women, which victimized the weak, undermined their human rights, and required state action to redress, was rendered irrelevant to the case. The judgment assumed that marriage contracts were merely private affairs, contrary to the feminist claim that the private is political.

Moreover, the court argued that the contested article of the Penal Code contradicted Article 24 of the constitution because it discriminated on the basis of religious beliefs. The judgment of the court stated with a formalistic liberal perspective, independent of context, that if unmarried couples who live together are not punished by law, then those who contract a religious marriage should not be discriminated against either. The objections of the court concerning Articles 20 and 24 assumed that there was gender equality in the social, economic, and political realms and that religious freedoms could be extended without circumscribing women's other rights and further empowering men. The court also assumed that everyone had equal knowledge of secular and Islamic laws and what they entailed.

To bolster their new interpretations as liberal and progressive, the judges who voted to revoke the existing Penal Code article referred to the European Convention on Human Rights and the European Court of Human Rights (ECHR). They cited Article 8 of the European Convention on the right to respect for private and family life and Article 9 on freedom of religion and conscience. They also referred to the ECHR rulings and mentioned how important these two rights were for the ECHR. They cited decisions on how the European Court extended the protection of the right to private life not merely to official but also to unofficial marriages (Constitutional Court 2015, 5). Notably, these were cases of custody for children born out of wedlock, which could be a problem in Turkey as well, if religious marriages increased. The references to the European Convention and the ECHR would, 
presumably, further legitimize interpretations of the Constitutional Court majority as liberal and in line with secularism, since both these institutions were seen as liberal and secular by many secular Turks.

Three of the dissenting judges made a case on legal grounds. They referred to a previous verdict on the same issue, in which the Constitutional Court had unanimously rejected the annulment of the contested article. They underlined the importance of Article 174 of the constitution specifying how legal marriages had to be contracted in line with the Civil Code. They pointed to the constitutional provisions that aimed to preempt challenges to secularism and previous court verdicts on the issue (Constitutional Court 2015, 9-15).

One of the dissenting judges argued on more substantive grounds. $\mathrm{He}$ pointed out that the Civil Code was based on male-female equality and underlined that constitutional Article 10 on equality had been strengthened to make the state explicitly responsible for realizing this equality. He argued that over $90 \%$ of the population reconciled their commitment to the Civil Code with their religious practices by contracting both civil and religious marriages and that there was no impending demand for change by this majority. The punishment concerned would be abated once the civil marriage was contracted and hence did not intend to punish religious marriage, but rather to enforce the Civil Code, which recognized women's rights. In his dissenting opinion, he also pointed out that the $3 \%$ who contracted only religious marriages were less educated and had lower socioeconomic status and that some sanctions were needed to eliminate the negative results of such marriages on family and society. He further argued that those living together without marriage were fewer than those married only with religious marriage. These two groups were also different in socioeconomic and educational backgrounds, and so it would be wrong to compare them in terms of their implications for gender equality and for society at large (Constitutional Court 2015, 15-18).

From a feminist point of view, the Constitutional Court's reinterpretation of the constitutional articles on the rights to privacy and religious belief was a threat to women's rights (Akyol 2015; Aşan et al. 2017). Even though the majority of the court declared Article 10 on equality to be irrelevant to the case, the dismissal of sanctions for avoiding civil marriage was problematic precisely because it could have unequal consequences for women. Religious marriage in a Muslim country meant Islamic law with polygamy, unilateral divorce by men, and unequal inheritance rights for women. Without sanctions, the 
number of women marrying only with a religious ceremony could increase. In a religious marriage, women are likely to be at least economically more dependent on men and in a structurally weaker position, as orthodox religious interpretations expect women to be. In a country like Turkey, where women are still less educated and economically less independent than men, they would be making a choice to contract a religious marriage instead of an official civil marriage under conditions of inequality, without equal substantive access to economic, social, and political power or information. Six years after the amendment of the Civil Code, which granted equal ownership of property acquired during marriage in cases of divorce, close to half the women in the country were unaware of this right (Altınay and Arat 2007, 98-99).

Women who married only with a religious ceremony would have no access to the protections the Civil Code provides, including the provision for a minimum marriage age, protection from polygamy, provision of equal inheritance rights, and protection in divorce. Prior to the registration of a civil marriage, state officials check that the partners meet the minimum age requirements of the Civil Code and that neither partner is officially married to another person so that multiple marriages can be prevented. In Turkey, child brides married before the age of 18 are a major problem, constituting about $15 \%$ of all marriages, even with the protections of the Civil Code (UNICEF 2016, 152). ${ }^{7}$ Young girls could be married off even more easily without the enforcement of an age requirement. The state enforces equal rights and legal responsibilities on both sides during marriage and upon divorce. This is crucial because women are likely to face poverty in cases of divorce, particularly because only one-third of women are in the labor force (Ministry of Family, Labor and Social Services 2019).

The scope of the protection that religious marriage offers women is controversial and interpreted differently in each country. Independent of this problem, there is no institution in secular Turkey to enact Islamic law for people who are married only with a religious ceremony. Thus, these women are left without even the weak protection that religious law could provide.

The Constitutional Court's verdict legalizing marriage according to Islamic law and without a civil marriage perforated the gender equality

7. The Civil Code has provisions that allow for marriage of girls under age 15 under special conditions. 
framework that the republic had defined. Appealing to liberal values, it initiated the unfolding of a religiously colored, illiberal gender framework in which the state encouraged traditional roles for women to complement male roles. This judgment was possible in secular Turkey only in a context of democratic backsliding, where the judiciary could adjudicate in line with the ideology of the aggrandized executive, and constitutional rights could be interpreted in line with this ideology rather than in the spirit of the secular constitution. In turn, the verdict helped the regime promote and legitimize a religiously inspired conservative ideology that would be the ideology of its emerging authoritarianism. Gender equality as a necessary if not sufficient condition of democratic rule was dismissed to expand religious rights, because at this point the emerging authoritarian regime needed to establish its religiously inspired ideological hegemony to entrench its rule. Expanding religious freedoms at the cost of gender equality would be normalized to build the culture of the new authoritarianism. The Civil Code that was protected by a special constitutional article as a founding law of the secular state was thus circumvented. The liberal reasoning used by the Constitutional Court served the needs of a hierarchical regime that increasingly restricted civil liberties and political freedoms to tilt the electoral field in its favor.

In October 2017, the parliament passed a law to allow religious personnel to perform civil marriages. Once again, giving the right to contract civil marriages to religious personnel could be interpreted as contrary to the spirit of Article 174, which aims to protect secularism, the Civil Code, and civil marriages. However, the government argued that this policy would facilitate registration of those who tried to contract only religious marriages by making it easier for them to contract a civil marriage (Uras 2017). Under the new circumstances, where couples need not contract a civil marriage prior to a religious one, there would be a tendency to skip the latter, even when religious personnel are given the right to perform the civil marriage ceremony. In Turkey, religious personnel are civil servants, yet it is doubtful that they would encourage civil marriages, especially under a religiously rooted government. Religious personnel are trained to respect and prioritize religious law (Lord 2018). It is not clear to what extent they believe in the importance of civil marriage. As officials who conduct religious marriages, which are not registered by the state, need not meet any minimum age requirement, and allow multiple marriages leading to polygamy, they would be likely to bypass these requirements of civil marriage. Thus, 
women can be deprived of the protection of the Civil Code, while child marriages and polygamy would increase.

Expanding only religious rights at the expense of other liberties does not promote free choice for women, particularly when civil liberties are increasingly restricted, the scope for criticism is narrow, and politicians in power are encouraging women in multiple ways to adopt traditional dependent roles that can restrict their options. Women can adapt their preferences to what is most easily available and ignore or undervalue what they think they cannot change or what is closed to them (Phillips 2007, 39). In Turkey, women were offered a broader range of religious options in less than free and less than equal circumstances, where an opponent could not expose their pitfalls. The new regime thus aimed to consolidate its conservative constituency, construct its ideological hegemony, legitimize, and normalize its increasingly authoritarian rule at the cost of jeopardizing women's civil rights.

\section{REPLACEMENT OF INSTITUTIONS}

A final strategy that Thelen delineates in the process of institutional change is displacement through the replacement of old institutions. This strategy developed in Turkey over time, beginning around 2011 and continuing to this day. The AKP displaced old institutions and replaced them with new ones to entrench its ideology, mobilize a conservative female constituency, and establish its own gender framework. One major displacement was the Ministry of State for Women and Family. The ministry was abolished in 2011 and replaced by the Ministry of Family and Social Policies, which was restructured in 2018 as the Ministry of Family, Labor and Social Services. The new ministry served as an umbrella institution for many groups and diverse interests besides women, including family, children, the disabled, the elderly, social services, and social aid. The abolition of a ministry for women to promote gender equality was a breach of international treaties that Turkey had signed, including CEDAW, and contrary to Article 10 of the constitution, which the AKP had amended to reinforce the state's responsibility for gender equality. The government recognized women merely as extensions of their families rather than as independent individuals with equal rights to men (Coşar and Özkan-Kerestecioğlu 2017, 163).

At the level of women's organizations, the AKP hoped to displace those established by feminists or secular women fighting for equal rights and 
replace them with conservative ones (Doyle 2018). The governing elites would be supporting women in civil society, but using this support to promote their conservative gender ideology and to create a conservative female constituency. KADEM - Kadın ve Demokrasi Derneği (Women and Democracy Association) - which was established in 2013 as a civil society organization, would serve this purpose. (Diner 2018). KADEM's relation to the state was unprecedented in the context of the second-wave women's movement in Turkey. The new association was organically linked to and supported by the AKP leadership. Sare Aydın Yılmaz, an AKP member who had worked in party administration and later became an AKP representative in the parliament, was the founding president of the association. Erdoğan's daughter Sümeyye Erdoğan was its vice president. KADEM endorsed the concept of complementarity between men and women. It sought "gender justice," rather than "gender equality," much like Erdoğan, who denied that there could be malefemale equality because men and women were created differently (Koyuncu and Özman 2019).

The new association promoted this view as an alternative to a feminist concept of equality without critically engaging with these terms. The feminist concept was reduced to a misleading understanding of equal rights in which equality was equated with sameness. President Sare Aydın Yllmaz argued that feminist equality led to the "masculinization" of women and a "detachment from the female identity" in an article that she wrote to elaborate KADEM's understanding of complementarity (Yllmaz 2015, 108). To defend gender justice, she argued that difference meant complementarity and claimed that feminists sought not difference but sameness. KADEM thus claimed to propose a new understanding of equality, which meant equivalence based on a functional division of labor between men and women, assigning traditional roles to each. The advocates of this perspective did not engage with the patriarchal consequences of this arrangement, whereby the economically weak would become dependent on and submissive to the economically strong. Even though Muslims believe that men and women are equal before God, complementarity could lead to a hierarchy of powers and a restriction of opportunities associated with power differentials. KADEM dismissed these issues.

In line with its concept of gender justice, which was based on a misreading of concepts of equality that feminists championed, KADEM endorsed various government initiatives related to women. For example, in support of the AKP government's foreign policy, KADEM sought to help Sunni Muslim migrant women from Syria and criticized the 
oppression of Muslim Rohingya women in Myanmar. It initiated social service projects, including organizing visits to houses for the elderly and preparing dinners to break the religious fast that the AKP party organization also promoted. It gave explicit political support to government as it mobilized women to vote for the AKP in elections.

KADEM's visibility and power increased as the political regime became more exclusionary of secular groups and restrictive of freedoms. In the critical 2017 referendum when Erdoğan changed the country's parliamentary system to a presidential system in order to aggrandize his rule, KADEM president Sare Aydın Yılmaz addressed women, arguing that the new system would liberate them. Aydin urged women to vote for the presidential system to "liberate justice and freedom from the yoke of tutelage and allow national will to reign" (Yllmaz 2017). This referendum took place under a state of emergency and in a context in which the separation of powers had already eroded and the opposition could not voice criticism (Bali 2018). How such a referendum would "liberate justice and freedom" was not problematized.

In turn, the government supported KADEM with material and symbolic state resources. President Erdoğan delivered the keynote speeches at conferences that KADEM organized, thus both honoring the association and having another medium to stigmatize feminists, for example by falsely claiming that they rejected maternity. Using KADEM's platform, he could reiterate his views on women's primary responsibilities as mothers and shape the views of his female constituency (Hürriyet 2014, 26). KADEM thus helped the government mobilize pious women and widen the rift between secular women who opposed the conservative authoritarian state and religious women who supported it.

By 2019, the association had representative offices in half the provinces in the country - a feat no other women's organization in the country had achieved (KADEM 2021). It had the resources to organize conferences and seminars, publish its own journal, and initiate projects in line with KADEM's and the government's gender complementarity agenda. KADEM became the main representative of Turkish women in international platforms and conferences. When Turkey hosted the G-20 meeting in 2015, it was KADEM, not any other established women's organization, that hosted the W-20. The AKP could thus displace secular women's civil society organizations that demanded equality and expansion of opportunities for women rather than the promotion of traditional roles at the same time that it was building an institution to mobilize a constituency of conservative women. 


\section{CONCLUSION}

This study contributes to the literature on regime type and gender rights by examining the instrumentalization of women's rights in Turkey during a process of regime change and the concurrent emergence of a conservative gender regime. It focuses not on a regime at a particular point in time, but rather on a regime that transformed over time from a weak democracy to an authoritarian regime. The literature on regime type and gender rights argues that different regimes have interests in using women's rights (Tripp 2019; Valdini 2019). Such is the case in Turkey as well. However, these interests change at different points in time during regime transformation. The instrumentalization of gender rights in Turkey bolstered the power of the governing elites by meeting different needs at different stages and contributed to the cultivation of a conservative gender framework that the newly authoritarian regime identified with. I bring in Thelen's work on institutional change to trace changes in and the instrumentalization of the gender framework during this transformation and explore its implications for the political regime. The article thus extends and contributes to Thelen's work on institutional change by developing its implications in the Turkish case.

In Turkey, unlike in other Muslim contexts, a conservative, religiously rooted political party, the AKP, came to power in a constitutionally secular state, promising to strengthen the secular democratic regime. Instead, in less than two decades, what emerged was a political regime with authoritarian features and a conservative gender framework. When the AKP first came to power through democratic elections, the governing elites used gender rights to assuage prevailing concerns that they would undermine the secular democratic state defined in the constitution. They also bolstered their international reputation by extending legal rights to women at a time when joining the $\mathrm{EU}$ was a goal they shared with a large majority beyond those who voted for them. This was in line with findings in the literature that democratic regimes tend to extend women's rights (Tripp 2013; Valdini 2019). Yet improvements in gender legislation did not have a substantive impact on improving women's predicament in Turkey, since they were not implemented. Liberal reforms were ignored. Extending women's rights was simply instrumental in protecting the AKP from the stigma of its religious background in a secular and democratic context.

Over time, the government increased its electoral power and enhanced its influence over the judiciary. It restricted civil and political rights and tilted the electoral process in its favor. Instrumentalizing women's rights 
to gain legitimacy was not necessary anymore. At this stage, with democratic backsliding in progress, the instrumentalization of women's rights served new needs. The judiciary could now interpret existing laws to the detriment of women and extend religious rights. Women's rights were threatened, even though there was still a need for recourse to liberal discourse to justify what was done. The regime aimed to use women's rights to cultivate its religiously rooted conservative ideology, challenging the prevailing secular egalitarian one. In the context of Thelen's theory, old laws served new ends. The competitive authoritarian regime benefited from such a judicial intervention to cultivate its conservative gender ideology while gender rights deteriorated. This was also a step in normalizing top-down rule-making by appealing to liberal arguments, while substantively undermining liberal rights. The ruling that challenged the foundational secular Civil Code was possible because it was becoming difficult to contest the power of an increasingly authoritarian regime.

Finally, the newly authoritarian regime needed neither legitimacy nor liberal legal justifications for its conservative ideology, but it could benefit from mobilizing a constituency of conservative women in support of the new regime. At this stage, the governing elites instrumentalized women's rights by supporting the institutionalization of these women in civil society. In the context of Thelen's framework, old institutions were being displaced through replacement. The establishment of KADEM, which was organically linked to the AKP, helped the party mobilize conservative women in support of the regime and AKP priorities. KADEM became the civil society organization that helped marginalize secular women's organizations in civil society. The authoritarian political regime was not interested in promoting equal rights for women, as some authoritarian governments did (Donno and Kreft 2019; Lorch and Bunk 2016), but in pushing its own religiously rooted conservative agenda from the top down and cultivating a constituency of conservative women.

The findings of this study support the argument in the literature that democratic regimes extend women's rights, but are contrary to findings that show authoritarian regimes promoting these rights. Most importantly, I show that a regime finds new aims and new strategies for instrumentalizing women's rights to reinforce its own power, even as its specific interests change with changes in the regime during a period of democratic backsliding. In the Turkish case, where a religiously rooted government came to power in a secular context, initial concerns for 
legitimacy and reputation gave way to the aim of redirecting existing legislation to expand religious rights at the cost of women's civil rights and finally establishing a conservative women's organization to mobilize a conservative female constituency. Meanwhile, at each stage, political leaders could claim to be improving women's rights: first by enhancing their rights to equality, then by extending their religious rights and protecting privacy and finally by supporting women in civil society. In Turkey, while the goals and strategies for instrumentalizing women's rights changed over time, they all contributed to the construction of a new political regime and a new gender ideology.

Yeşim Arat is a Professor in the Department of Political Science and International Relations at Bogazici University, Istanbul, Turkey: araty@ boun.edu.tr

\section{REFERENCES}

Acar, Feride, and Gülbanu Altunok. 2013. “The 'Politics of Intimate' at the Intersection of Neo-Liberalism and Neo-Conservatism in Contemporary Turkey." Women's Studies International Forum 41 (Part 1): 14-23.

Adams, Melinda Adams. 2007. "National Machineries' and Authoritarian Politics." International Feminist Journal of Politics 9 (2): 176-97.

Akkan, Başak. 2018. "The Politics of Care in Turkey: Sacred Familialism in Changing Political Context." Social Politics 25 (1): 72-91.

Aksoy, Hürcan Asl. 2015. "Invigorating Democracy in Turkey: The Agency of Organized Islamist Women.” Politics \& Gender 11 (1): 146-70.

- 2018. "Gendered Strategies between Democratization and Democratic Reversal: The Curious Case of Turkey." Politics and Governance 6 (3): 101-11.

Akyol, Raida Asimovic. 2015. “Turkish Court Stirs Marriage Debate.” Al Monitor, June 1.

Altınay, Ayşe Gül, and Yeşim Arat. 2007. Türkiye’de Kadına Yönelik Şiddet [Violence against women in Turkey]. Istanbul: Punto.

Arat, Yeşim. 1997. "The Project of Modernity and Women in Turkey." In Rethinking Modernity and National Identity in Turkey, eds. Sibel Bozdoğan and Reşat Kasaba. Seattle: University of Washington Press, 95-112.

_. 1998. "Feminists, Islamists and Political Change in Turkey." Political Psychology 19 (1): 117-31.

- 2008. "Contestation and Collaboration: Women's Struggles for Empowerment in Turkey." In The Cambridge History of Turkey, vol. 4, Turkey in the Modern World, ed. Reşat Kasaba. Cambridge: Cambridge University Press, 388-418.

Arat, Yeşim, and Şevket Pamuk. 2019. Turkey between Democracy and Authoritarianism. Cambridge: Cambridge University Press.

Arslanalp, Mert, and Deniz Erkmen. 2020. "Mobile Emergency Rule in Turkey: Legal Repression of Protests during Authoritarian Transformation.” Democratization 27 (6): 947-69.

Aşan, Esra, et al. 2017. “Yeni Türkiye’de” Kadın ve Çocuk Hakları Üzerine Hülya Gülbahar ile Söyleşi” [A conversation with Hülya Gülbahar on women and children's rights in “New Turkey”]. BÜ'de Kadın Gündemi 32 (Spring): 35-49. 
Ayata, Ayşe Güneş, and Gökten Doğangün. 2017. "Gender Politics of the AKP: Restoration of a Religio-conservative Gender Climate." Journal of Balkan and Near Eastern Studies 19 (6): 610-27.

Bakıner, Onur. 2017. "How Did We Get Here? Turkey's Slow Shift to Authoritarianism.” In Authoritarian Politics in Turkey: Elections, Resistance and the AKP, eds. Bahar Başer and Ahmet Erdi Öztürk. London: I.B. Tauris, 21-46.

Bali, Aslı. 2018. “Turkey's Constitutional Coup.” Middle East Report 288 (Fall): 2-9.

Bermeo, Nancy. 2016. "On Democratic Backsliding." Journal of Democracy 27 (1): 5-19.

Bianet. 2019. "Withdraw the Motion Foreseeing Marriage Amnesty for Child Abusers." January 22. https://bianet.org/english/women/204710-withdraw-the-motion-foreseeingmarriage-amnesty-for-child-abusers (accessed July 9, 2021).

Bush, Sarah Sunn, and Pär Zetterberg. 2021. "Gender Quotas and International Reputation.” American Journal of Political Science 65 (2): 326-41.

Çalışkan, Koray. 2018. "Toward a New Political Regime in Turkey: From Competitive toward Full Authoritarianism." New Perspectives on Turkey 58: 5-33.

Candaş, Ayşen, and Yıldız Silier. 2013. "Quietly Reverting Public Matters into Private Troubles: Gendered and Class-Based Consequences of Care Policies in Turkey." Social Politics 21 (1): 103-23.

Celis, Karen, Johanna Kantola, Georgina Waylen, and S. Laurel Weldon. 2013. "Introduction: Gender and Politics: A Gendered World, a Gendered Discipline." In The Oxford Handbook of Gender and Politics, eds. Georgina Waylen, Karen Celis, Johanna Kantola, and S. Laurel Weldon. Oxford: Oxford University Press, 1-27.

Cindoğlu, Dilek, and Didem Ünal. 2017. "Gender and Sexuality in the Authoritarian Discursive Strategies of 'New Turkey." European Journal of Women's Studies 24 (1): 39-54.

Constitutional Court of the Republic of Turkey. 2015 "Judgement of the Constitutional Court. No 2015/51.” May 27. https://anayasa.gov.tr/media/2585/2015-51.pdf (accessed July 5, 2021).

Coşar, Simten, and İnci Özkan-Kerestecioğlu. 2017. "Feminist Politics in Contemporary Turkey: Neoliberal Attacks, Feminist Claims to the Public." Journal of Women, Politics \& Policy 38 (2): 151-74.

Coşar, Simten, and Metin Yeğenoğlu. 2011. "New Grounds for Patriarchy in Turkey? Gender Policy in the Age of AKP." South European Society and Politics 16 (4): 555-73.

Csaky, Zselyke. 2021. "Nations in Transit: The Antidemocratic Turn." Freedom House. https://freedomhouse.org/report/nations-transit/2021/antidemocratic-turn (accessed June 14, 2021).

Dağı, Ihsan. 2006. "The Justice and Development Party: Identity, Politics and Discourse of Human Rights in the Search for Security and Legitimacy." In The Emergence of a New Turkey, ed. Hakan Yavuz. Salt Lake City: University of Utah Press, 88-106.

Dedeoğlu, Saniye, and Adem Yavuz Elveren, eds. 2012. Gender and Society in Turkey: The Impact of Neoliberal Policies, Political Islam and EU Accession. London: I.B. Tauris.

Diamond, Larry. 1996. "Is the Third Wave Over?" Journal of Democracy 7 (3): 20-37.

- 2015. "Facing Up to the Democratic Recession." Journal of Democracy 26 (1): 141-55.

Diner, Çağla. 2018. "Gender Politics and GONGOs in Turkey." Turkish Policy Quarterly 16 (4): 101-8.

Diner, Çăgla, and Şule Toktaş. 2010. "Waves of Feminism in Turkey: Kemalist, Islamist and Kurdish Women's Movements in an era of Globalization." Journal of Balkan and Near Eastern Studies 12 (1): 41-57.

Donno, Daniela, and Anna Kathrin Kreft. 2019. “Authoritarian Institutions and Women's Rights." Comparative Political Studies 52 (5): 720-53.

Doyle, Jessica Leigh. 2018. "Government Co-option of Civil Society: Exploring the AKP's Role within Turkish Women's CSOs.” Democratization 25 (3): 445-63. 
Esen, Berk, and Şebnem Gümüşcü. 2016. "Rising Competitive Authoritarianism in Turkey." Third World Quarterly 37 (9): 1581-1606.

Freedom House. 2018. "Freedom in the World 2018: Democracy in Crisis." https:// freedomhouse.org/report/freedom-world/freedom-world-2018 (accessed June 14, 2021).

Hürriyet. 2014. "Kadın-erkek eşitliği fitrata ters" [Female-male equality against nature]. November 25, 26.

KADEM. 2021. "KADEM İl Temsilcilikleri” [KADEM provincial representatives]. http:// kadem.org.tr/temsilcilikler/ (accessed July 9, 2021).

Kalaycıŏlu, Ersin. 2012. "Kulturkampf in Turkey: The Constitutional Referendum of 12 September 2010." South European Society and Politics 17 (1): 1-22.

- 2018. "Two Elections and a Political Regime in Crisis: Turkish Politics at the Crossroads." Southeast European and Black Sea Studies 18 (1): 21-51.

Kandiyoti, Deniz. 2016. "Locating the Politics of Gender: Patriarchy, Neo-liberal Governance and Violence in Turkey." Research and Policy on Turkey 1 (2): 103-18.

Koç, Handan. 2010. "Referandumda Feminizmin İcabı Bence Hayır" [According to me feminism requires the no vote to the referendum]. Bianet, September 2. https:// bianet.org/bianet/siyaset/124545-referandumda-feminizmin-icabi-bence-hayir (accessed July 8, 2021).

Koyuncu, Berrin, and Aylin Özman. 2019. “Women’s Rights Organizations and Turkish State in the Post-2011 Era: Ideological Disengagement versus Conservative Alignment." Turkish Studies 20 (5): 728-53.

Kubicek, Paul. 2011. "Political Conditionality and European Union's Cultivation of Democracy in Turkey." Democratization 18 (4): 910-31.

Levitsky, Steven, and Lucan Way. 2002. "Elections without Democracy: The Rise of Competitive Authoritarianism." Journal of Democracy 13 (2): 51-65.

Lorch, Jasmin, and Bettina Bunk. 2016. "Gender Politics, Authoritarian Regime Resilience, and the Role of Civil Society in Algeria and Mozambique." Working Paper 292, German Institute of Global and Area Studies. https://www.econstor.eu/ bitstream/10419/147547/1/870609602.pdf (accessed June 14, 2021).

_ 2017. "Using Civil Society as an Authoritarian Legitimation Strategy: Algeria and Mozambique in Comparative Perspective." Democratization 24 (6): 987-1005.

Lord, Ceren. 2018. Religious Politics in Turkey: From the Birth of the Republic to the AKP. Cambridge: Cambridge University Press.

Mama, Amina. 2013. "Women in Politics." In Routledge Handbook of African Politics, eds. Nicholas Cheeseman, David Anderson, and Andrea Scheibler. New York: Routledge, 147-62.

Marshall, Gül. 2009. "Authenticating Gender Policies through Sustained-Pressure: The Strategy behind the Success of Turkish Feminists." Social Politics 16 (3): 358-78.

Ministry of Family, Labor and Social Services. 2019. "Women in Turkey 2019." https:// ailevecalisma.gov.tr/media/5262/women-in-turkey-2019.docx (accessed June 14, 2021).

Morelli, Vincent. 2010. "European Union Enlargement: A Status Report on Turkey's Accession Negotiations." Report RS 22517, Congressional Research Service, April. https://crsreports.congress.gov/product/pdf/RS/RS22517/35 (accessed June 14, 2021).

Müftuiler-Baç, Meltem. 2005. "Turkey's Political Reforms and the Impact of the European Union." South European Society and Politics 10 (1): 17-31.

O’Donnell, Guillermo, and Phillippe C. Schmitter. 1986. Tentative Conclusions about Uncertain Democracies. Vol. 4. Baltimore: John Hopkins University Press.

Öniş, Ziya, and E. Fuat Keyman. 2003. "Turkey at the Polls: A New Path Emerges." Journal of Democracy 14 (2): 95-107.

Özbudun, Ergun. 2006. "From Political Islam to Conservative Democracy: The Case of the Justice and Development Party in Turkey.” South European Society \& Politics 11 (3-4): $543-57$. 
2015. "Turkey's Judiciary and the Drift toward Competitive Authoritarianism." The International Spectator 50 (2): 42-55.

Pelek, Semra. 2010. "Gülbahar: Başbakan Kadınların Taleplerini Görmezden Geldi” [Gülbahar: The prime minister ignored women's requests]. Bianet, July 19. http:// bianet.org/kadin/siyaset/123540-gulbahar-basbakan-kadinlarin-taleplerini-gormezdengeldi (accessed June 14, 2021).

Phillips, Anne. 2007. Multiculturalism without Culture. Princeton, NJ: Princeton University Press.

Sarıhan, Şenal. 2005. Türk Ceza Kanunu Kadınlara Neler Getiriyor? [What the Turkish penal code brings to women]. Ankara: İl Özel İdaresi Genel Sekreterliğii.

Sika, Nadine, and Yasmin Khodary. 2012. "One Step Forward, Two Steps Back? Egyptian Women within the Confines of Authoritarianism." Journal of International Women's Studies 13 (5): 91-100.

Svedberg, Douglas. 2019. “Gaining International Legitimacy by Improving Women's Rights and Gender Equality: The Case of Nicaragua." Bachelor's thesis, Uppsala University.

Tekeli, Şirin. 1986. "Emergence of the Feminist Movement in Turkey." In The New Women's Movement, ed. Drude Dahelrup. Beverly Hills, CA: Sage, 179_99.

- 2010. “The Turkish Women's Movement: A Brief History of Success." Quaderns de la Mediterrània 14: 119-23.

Thelen, Kathleen. 2011. "Beyond Comparative Statics: Historical Institutional Approaches to Stability and Change in the Political Economy of Labor." In The Oxford Handbook of Comparative Institutional Analysis, eds. Glenn Morgan, John L. Campbell, Colin Crouch, Ove Kaj Pedersen, and Richard Whitley. New York: Oxford University Press, 41-61.

Tocci, Nathalie. 2005. “Europeanization in Turkey: Trigger or Anchor for Reform?” South European Society and Politics 10 (1): 73-83.

Tripp, Aili Mari. 2013. "Political Systems and Gender." In The Oxford Handbook of Gender and Politics, eds. Georgina Waylen, Karen Celis, Johanna Kantola, and S. Laurel Weldon, Oxford: Oxford University Press, 514-35.

- 2019. Seeking Legitimacy: Why Arab Autocracies Adopt Women's Rights. Cambridge: Cambridge University Press.

Ulukaya, Ceyda. 2015. "Kadınları Kim, Nerede, Nasıl Öldürdü: 5 Yılın Cinayet Haritası" [Who murdered women, where and how: A homicide map of 5 years]. Bianet, November 24. https://m.bianet.org/bianet/kadin/169494-kadinlari-kim-nerede-nasiloldurdu-5-yilin-cinayet-haritasi (accessed July 8, 2021).

UNICEF. 2016. The State of the World's Children, 2016: A Fair Chance for Every Child. New York: UNICEF.

Uras, Umut. 2015. “Turkey Court Ruling on Religious Marriages Spurs Uproar.” Al Jazeera, May 30. http://www.aljazeera.com/news/2015/05/turkey-court-ruling-religiousmarriages-spurs-uproar-150530151909516.html (accessed June 14, 2021).

_ 2017. “Turkey: Religious Officials to Perform Civil Marriages," Al Jazeera, October 19. https://www.aljazeera.com/news/2017/10/turkey-religion-officials-perform-civil-marriages171019132948431.html\#: :text=The\%20Turkish\%20parliament\%20has\%20passed, authorised\%20to\%20conduct\%20such\%20ceremonies. (accessed June 14, 2021).

Valdini, Melody. 2019. The Inclusion Calculation: Why Men Appropriate Women's Representation. Oxford: Oxford University Press.

Waldner, David, and Ellen Lust. 2018. "Unwelcome Change: Coming to Terms with Democratic Backsliding." Annual Review of Political Science 21: 93-113.

World Bank. 2020. "Labor Force, Female (\% of Total Labor Force) - Turkey." https://data. worldbank.org/indicator/SL.TLF.TOTL.FE.ZS?locations=TR (accessed July 8, 2021). 
Yavuz, Hakan. 2009. Secularism and Muslim Democracy in Turkey. Cambridge: Cambridge University Press.

Yllmaz, Hakan. 2005. "Swinging between Eurosupportiveness and Euroskepticism: Turkish Public's General Attitudes towards the European Union.” In Placing Turkey on the Map of Europe, ed. Hakan Yllmaz. Istanbul: Bogazici University Press, 152-81.

Yllmaz, Sare Aydın. 2015. "A New Momentum: Gender Justice in the Women's Movement.” Turkish Policy Quarterly 13 (4): 107-15.

. 2017. "Kadın ve Demokrasi Buluşması-2" [Meeting of women and democracy]. KADEM, March 5. http://kadem.org.tr/kadin-ve-demokrasi-bulusmasi-2-sare-aydinkonusma-metni/ (accessed July 9, 2021). 